INTERNATIONAL JOURNAL OF MULTIDisciplinARY RESEARCH AND ANALYSis

ISSN(print): 2643-9840, ISSN(online): 2643-9875

Volume 05 Issue 02 February 2022

DOI: 10.47191/ijmra/v5-i2-30, Impact Factor: 6.072

Page No. 446-451

\title{
Social Studies Teacher's Perception in the Use of Educational Websites in Online Teaching in the Philippines: A Systematic Literature Review
}

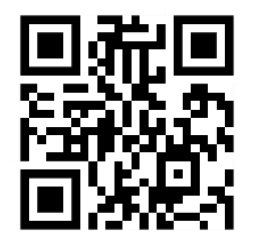

\section{Jeanel C. Gregorio}

ABSTRACT: The pandemic has challenged the educational system to alter the delivery of instruction from the traditional face-toface into distant learning, modular and online. This sudden paradigm shift posited a lot of concerns particularly in the integration of technology in social studies curriculum. This review used the systematic literature review to analyze the empirical literature and the reading log (University of South Australia) to analyze the findings. The systematic literature is a rigorous approach in searching related literature, identifying publications to be included to undergo an iterative and transparent processes, analyze the data through a structured abstraction and a systematic approach (Gentles, S.J. et. al. 2016). This review found out that there is a limited literature in the integration of technology specific in social studies both internationally and in the Philippine context. Although there are some literature on technology integration in social studies, they failed to tackle the experiences and challenges by the teachers in technological integration in full online delivery of instruction specific in social studies teaching. Thus, it is recommended that researchers must explore other angles of technological integration in social studies such as the teacher's perceptions of specific technologies used in the subject. Second, the experiences and challenges they encountered during the delivery of instruction amidst the crisis. Third, studies should also be conducted on the effect of technology integration to student outcomes. These studies will serve as the basis for the future planning, design, implementation, assessment, and modification of social studies curriculum to be more student centered, contextualized and inclusive with the use or aid of technologies.

\section{INTRODUCTION}

The internet and newly developed technologies defined today's society. Even amidst the pandemic, education was pursued due to the alternatives offered by technology, most especially with the advent of using the internet. It bridges the gap between each other to communicate, socialize, run errands, do business, and attend school even at the comfort of our homes. In education, the e-learning tools and various online platforms have played a vital role in delivering education, helping basic and tertiary education institutions to facilitate student learning during the school closure (Subedi et al., 2020). Hence, the use of relevant pedag ogy for online education was seen as an alternative but the effectiveness may vary on the expertise and exposure of teachers to information and communications technology (ICT). The use of educational websites has been the trend as the educational system engaged in a paradigm shift. Some of the online platforms used worldwide must be a unified communication and collaboration platforms such as G-Suite (Google Classroom, Google Meet, etc.), Zoom, Microsoft Teams, Canvas and Blackboard, which allow the teachers to create educational courses, training and skill development programs (Petrie, 2020).

In the Philippines, the crisis required an abrupt exodus from the traditional face-to-face interaction to virtual and modular learning, hence faces challenges among the Filipino teachers and learners in terms of access and engagement in these new modalities. The Department of Education (DepEd) released the Basic Education Learning Continuity Plan (BE-LCP) which serves as the blueprint to what and how education would be during the crisis, along with the Most Essential Learning Competencies (MELCs). These plans are anchored on the 'Sulong Edukalidad' (Advancement of Quality Education) framework which modified the curriculum and became the basis of the Philippine education aligned in the present situation of the country. Further, UNESCO reiterated that learning quality, access, and system strengthening cannot be compromised in times of crisis (UNESCO, 2017), or else would have a negative effect on human capital. The Department of Education was committed to comply with UNESCO's call and sustain the delivery of quality, relevant, accessible and liberating Philippine education system even during the crisis as stated in one of the Sustainable Development Goals, quality education for all. These initiatives resulted in the adaptation of online and modular learning modalities. 
Social Studies Teacher's Perception in the Use of Educational Websites in Online Teaching in the Philippines: A
Systematic Literature Review

Thus, online learning became a new phenomenon among Filipino learners and teachers. Training and webinars were conducted in various institutions to look for other alternatives for educational continuity. There are 50,000 public schools shifted into home-based instruction and 24 million students are expected to receive teaching instructions online, in modular, in television and radio (Mendoza, 2020). While the public school adopted the modular and TV or radio based instructions, many private schools opted to adopt the online modalities. Hence, tenured teachers find ways to adapt to the changes, learning materials were modified to fit in the learning modality adapted by their respective institution - online, blended, or modular. The effects of online learning in the overall well-being of the teachers and students are among the considerations that needed to be discussed with.

This altered reality in the education system has affected the teachers, much more, in social studies whose end goal is to develop the civic engagements among the students. Technological knowledge in teaching social studies, affects teachers' perception on the appropriate educational technologies to be used in the classes (Crawford \& Kirby, 2008). The lack of technological knowledge could lead to a tendency for social studies teachers to swing back in the traditional way of teaching. The teachers' use of technological applications in their lessons is associated with their skills and self-efficacy in using technology (Friedman and Heafnee, 2010 as cited by Fidan, 2017).

This paper seeks to systematically analyze the existing literature using the systematic literature review in the use or integration of technologies and educational websites in online teaching of social studies in the Philippines. This paper shall serve as the basis of future research studies in curriculum development, planning, modification, and implementation in social studies.

\section{METHODOLOGY}

To determine the effectiveness and the use of educational websites in facilitating learning in social studies, this paper has been made to conduct a systematic methods overview. A term used to refer to reviewing the methods of literature from various sources - preferably, peer-reviewed journals. In this methodology, literature consulted for such reviews may include the methodology of the literature, methods-relevant sections of empirical research reports, or both (Gentles, 2016). It involves a rigorous and transparent approach in searching for the methods literature points at reviewing and selecting the influential publications. The insights presented in this paper were presented based on the findings of the systematic overview. The methods literature was firmly established, where the possible publication types include journal articles, books, and book chapters while the methodsrelevant sections of empirical study reports, was poorly enforced due to the limited number of scholarly articles about technology integration in Social Studies in prominent Social Sciences and Humanities journals.

The systematic approach was used over an authoritative narrative approach to ensure that the review was accountable and thorough. Some studies were highlighted in terms of their methodology and goal to give light to other angles or areas that needed to be explored. The purposeful sampling was utilized in selecting publications in relation to integration of technologies and websites in social studies, the teacher's perception in utilizing these technologies, and their benefits for both teachers and students. The Reading Log introduced by University of South Australia was used to categorize the major points of each literature and is the basis for analysis and cross-examination of sources.

\section{TECHNOLOGY ACQUISITION, USAGE, AND ROLE IN SOCIAL STUDIES}

Various research studies were conducted prior to the pandemic to suggest the effectiveness of the integration of technology in Social Studies education to better effectively and efficiently facilitate learning in the $21^{\text {st }}$ century. The study of Jančič, Polona (2018) on the teaching of social studies with the use of games, found that game-based learning enables an optimal learning environment for students and role-playing approach was cited as the most commonly used. However, results show that teachers rarely use game-based learning in teaching social science. Thus, it recommended the national curriculum to include experiential learning with games in teaching social studies (Jančič, 2018). This study focuses on the application of games in the face-to-face setting.

While Jančič (2018) focuses on the integration of game-based approach in social studies, Çetin (2010) as cited by (Fidan, 2017) supported this claim through the participants' claim that they become happier when a high number of elements such as activity, experiment, game and animation are integrated in the content of the curriculum through web-supporting teaching activities. A high number of processing questions during the web-based activities and games could provide reinforcement.

The integration of technology in teaching social studies allowed the teachers to escape from the traditional classroom approaches and explore more frontiers to facilitate learning effectively. Heafner (2013) provided insights about the teacher's perception of secondary social studies teachers. These include: a) provide opportunities for students to extend their learning in their homes, b) the development of student's cognitive skills for independent learning, c) address the student's learning 


\section{Social Studies Teacher's Perception in the Use of Educational Websites in Online Teaching in the Philippines: A}

Systematic Literature Review

deficiencies, d) allows the teacher to explore other platforms to present the instructional material to cater learner's varied learning styles (Heafner, 2013).

The literature in the Philippines revolves around the use of the Technological Pedagogical Content Knowledge (TPACK) framework in integrating appropriate technologies in teaching and the Will-Skill-Tool (WST) framework in both Science and Mathematics (Mercado, J. N., et. al, 2019 \& Sasota, 2021). Both studies asserted the effective use of technology in both Science and Mathematics and suggested for teacher's training for the improvement of technological pedagogical knowledge. These studies are however limited in Science and Mathematics only.

The common denominator derived from these literatures is the ability to encourage the readers on integrating technology in the Social Studies curriculum. Based on the results, interactive educational websites should be commonly used by social studies teachers (Fidan, 2017). Thus, authors accept the reality that online instruction is a permanent fixture in education (Tschida, 2013). All teachers should be oriented and encouraged to use these websites (Çiftçi \& Alemdar 2013). While these literatures focus on the integration of social studies in online teaching, the methodology was conducted in face-to-face interaction. For instance, the study of Heafner (2013) about the teacher's perception in technology integration was conducted in the face-toface setting, not in a pure online environment. In the Philippines, there is no accessible research study pertaining to online teaching specific to social studies. This could lead to a presumption that this area needs to be explored. Both international and local literature could not provide answers as to what extent is the use of technology in social studies nor assess the experiences of learners and teachers in full online teaching in the subject during the crisis (Vanfossen, 2001).

\section{PERCEPTIONS ON THE INTEGRATION OF WEBSITES IN SOCIAL STUDIES}

A website consists of a group of pages that can be accessed using the internet. It provides an interactive interface among the users. In this context, the website refers to the educational tool used to facilitate learning, provide teaching-learning interaction, assess student's outputs, and deliver teaching instructions. Hence, in the academic literature, websites can be used as a source of information, as a tool for assessment, and as a platform to produce and share a product. (Dinç, 2017).

Based on the studies of Fidan (2017) and Tschida (2013) on the teacher's perception on the integration of educational websites in teaching social studies, they come up with useful websites. Some of these are Morpa Kampüs and Okulistik, Vitamin and partially, EBA, Blackboard, Camtasia, VoiceThread, and Prezi. These websites are found to be useful in delivering the content and student's assessment. They highlighted that they include various technologies to make the lessons more engaging with the content and teaching strategies (e.g., theoretical and content background readings, activities, discussion boards, videos). These websites enable the learners to enjoy the class and access information whenever or wherever they are. These help them also to learn by experience (Fidan, 2017). On the other hand, these websites are available more than three years ago and the technologies have quite developed in a short span of time. Now, the famous video conferencing used in online class and online engagement is Zoom, as of 2021. Other institutions adapted their own Learning Management System (LMS) while some adapted the G-Suite that includes Google Classroom, Google Meet (video conference), Google Slide (presentations), Google Docs etc. (Kormos, et. al. 2016) asserted that the document creation applications or websites were perceived as effective and commonly used internet-based technology. Some examples of these are the Google Docs or Microsoft 365. These educational websites have defined online teaching in times of crisis.

Social Studies teachers are the enforcers of educational websites. The outcome of the integration of technology in the field, satisfactory or not, could affect the teachers' pedagogy, much more than their well-being. Fidan (2017), Çiftçi \& Alemdar (2013), and Heafner (2013) gathered teachers' perception on the use of educational websites in teaching social studies. All agreed that the aforementioned technologies could enable teachers to be better prepared and well-equipped, make classes become more entertaining, and help the teachers become efficient and convenient in delivering the instruction as students easily access the intended and the large amount of information used in the lesson (Fidan, 2017). Moreover, technology use promotes independent learning and students' cognitive skills. (Heafner, 2013).

Since 2012 up to 2017, the research studies on student's perception in integrating educational websites in the curriculum bears positive results. The use of documentary films and videos about historical subjects, events, and natural disasters was found to be effective. Based on the study of Adeyemi (2012) and Fidan (2017), technology integration significantly improved the student's motivation in Social Studies, and thus, enhanced their academic performance. Students expressed that the text-based discussions and projects done online were perceived positively and that the visuality precipitated positive changes in their attitudes toward social studies. Online learning promoted the positive attitude of the students in social studies. (Tschida, 2013; Çiftçi, 2013; Heafner, 2013). 


\section{Social Studies Teacher's Perception in the Use of Educational Websites in Online Teaching in the Philippines: A}

Systematic Literature Review

Based on the findings of the literature, there was a positive view on integrating websites and technology in delivering the instruction. It was recommended that the teachers are highly encouraged to include inactive education websites in delivering their content. Study participants reported that the use of interactive education websites in social studies classes offers many ben efits to teachers and students. Further, the studies revealed personal trial and error as the most likely way to acquire new technological knowledge to prepare the learning materials (Fidan, 2017).

\section{THE CHALLENGES OF TECHNOLOGY INTEGRATION IN SOCIAL STUDIES}

Prior to the pandemic, institutions opted to integrate technology in their classroom faces challenges and problems. Though teachers who share their ideas on technology integration in the field have high levels of motivation (Johnson et al., 2015 as cited by Kormos, 2016), Vanfossen as cited by Heafner (2013) asserted that the major barrier in integrating technology in social studies curriculum is the lack of teacher training. Based on his findings, half of the respondents indicated they rarely integrate technologies and websites in teaching social studies. Further, Heafner's (2013) study revealed that internet outage or disconnection was found to be the barrier in delivering the instruction which consumes time while trying to implement the curriculum (Heafner, 2013).

To understand the current practices by teachers who are integrating technologies in the field, prepares future social studies educators. The need for training among the teachers could provide the success in administering technology in the classroom (Heafner, 2013). Secondary social studies teachers must develop a well-educated citizenry who are empowered with both cognitive and technological skills to become informed decision makers and productive and competitive workers (Heafner, 2013). Hence, the training programs should be carried out to a more effective curriculum in social studies (Kormos, et. al. 2016). Training programs and webinars must address the websites useful in delivering the instruction such as Google Docs, Slides, Meet, and Classroom to offer a variety of formats to demonstrate understanding and knowledge in a medium of the student's choice. Further, they may seek collaboration with other subject areas so as to provide curricular alignment in the integration of these technologies

The integration of technology was recommended to go beyond the four corners of the classroom. The student's learning is challenged and prepares them to be active agents in national policy and civic engagements. Further, it enhances learning outside from the readily available materials in the school and alters the nature of learning into a more student and independent learning. Hence, Kormos, et. al. 2016 recommended that the government must engage in studies that promote appropriate use of technology in the learning settings.

Technology is used in the classroom as a referencing, a communication, and a collaboration platform. However, not all teachers are digital-natives. These teachers have undergone rigorous training and review to adapt the changes in delivering the instructions. Teachers who experience difficulty in meeting the demands of the digital world creates a digital competency gap between the students. The digital inequality in schools based on the students' capacity to use technology for academic purposes has been found to be associated with teachers' technological capacity and interventions. (Nueva, 2019)

In the Philippines, the study of Abante, et. al. (2021) is the most recent on the Comparative Analysis on the Challenges of Online Learning Modality and Modular Learning Modality. The challenging part is the lack of training among the teachers in delivery of online teaching and assessment. The study is limited only to the overall challenges of the teachers in private and public school but does not focus on the use of technology in online class. In higher education institution, among the issues and challenges are: the ability to clearly deliver the topic, lack of study of working area and time in doing online activities, poor internet connection among the teachers and students, and the ability of the instructors/professors to cater the needs of the students (Fabito, 2020). Hence, there is a greater need for the educational institutions to proliferate studies on the impact of the pandemic to the educational system. Strengthening the practices in the curriculum for it to be more responsive to the students beyond the four corners of the classroom was among the recommendations (Toquero, 2020). Abante, et. al. (2021); Fabito, 2020; Toquero, 2020 focus primarily on the experiences of both teachers and students in coping up the online class amidst the pandemic. However, there are no available literature specifying the experiences of social studies educators in the use of technology in online teaching.

\section{CONCLUSION}

The aforementioned studies were the result of the rigorous effort of various institutions to contribute knowledge in the field of social studies. Prior to the pandemic, there were various studies conducted primarily in Turkey and other countries in West Asia. However, due to language barriers, the researcher finds difficulty in transcribing the texts. Hence, the study of Heafner (2013) and Fidan (2017) were the major basis. While Heafner (2013) has focused on the perceived technology integration, Fidan (2017) looked into the teacher's perception on the use of educational websites in social studies teaching. Further, Kormos (2016) examined the use of preservice social studies educators in technology integration. 
Social Studies Teacher's Perception in the Use of Educational Websites in Online Teaching in the Philippines: A
Systematic Literature Review

Empirically, there is a limited literature in the integration of technology in social studies particularly in the Philippine context. Therefore, this review may serve as the guide or the basis for future studies in the social studies online teaching. It is highly recommended that researchers must explore the areas of social studies in terms of perceptions of specific technologies used, teacher and student experiences in integrating websites and technologies, and the challenges encountered by the social studies teacher in times of pandemic. Studies on the effect of technology integration in delivering the instruction to student outcomes are also recommended. These studies will serve as the basis for the future planning, design, implementation, assessment, and modification of social studies curriculum to be more student centered, contextualized and inclusive with the aid of technologies.

\section{REFERENCES}

1) Abante, A. S. (2021). A Comparative Analysis on the Challenges of Online Learning Modality and Modular Learning Modality: A Basis for Training Program. Cabrera Department of Education and La Consolacion University Philippines https://www.ijmra.in/v4i4/Doc/17.pdf

2) Adeyemi, Deniyi (2012). Effects of Computer Assisted Instruction (CAI) on Students' Achievement in Social Studies in Osun State, Nigeria. Researchgate.com https://www.researchgate.net/publication/287498782_Effects_of_Computer_Assisted_Instruction_CAI_on_Students'_ Achievement_in_Social_Studies_in_Osun_State_Nigeria

3) Çiftçi, T. \& Alemdar (2013). The Opinions of Classroom Teachers about Fatih Project. Researchgate.com https://www.researchgate.net/publication/279188302_The_Opinions_of_Classroom_Teachers_about_Fatih_Project

4) Crawford, E. O. \& Kirby M. M. (2008). Fostering Students' Global Awareness: Technology Applications in Social Studies Teaching and Learning. Journal of Curriculum and Instruction (JoCl), https://www.researchgate.net/publication/26498775_Fostering_Students'_Global_Awareness_Technology_Applicatio ns_in_Social_Studies_Teaching_and_Learning.

5) Dinç, Emre. (2017). Web-based Education and Accessibility. International Journal of Technology in Education and Science (IJTES). https://www.researchgate.net/publication/329075848_Web-based_Education_and_Accessibility

6) Fabito, B. S. et. al. (2020). Barriers and Challenges of Computing Students in an Online Learning Environment: Insights from One Private University in the Philippines https://arxiv.org/abs/2012.02121

7) Fidan, N. K. (2017). Teachers' Views on the Use of Interactive Education Websites in Social Studies Classes. Afyon Kocatepe University, Faculty of Education, Afyonkarahisar-Turkey. The Online Journal of Science and Technology. Volume 7, Issue 3 http://www.tojned.net/journals/tojsat/articles/v07i03/v07i03-13.pdf

8) Gentles, S.J. et. al. (2016). Reviewing the research methods literature: principles and strategies illustrated by a systematic overview of sampling in qualitative research. Department of Clinical Epidemiology and Biostatistics, McMaster University, Hamilton, Ontario, Canada. https://link.springer.com/content/pdf/10.1186/s13643-016-0343-0.pdf

9) Heafner, T. (2013). Secondary Social Studies Teachers' Perceptions of Effective Technology Practice, International Journal of Computer and Information Technology, 2(2), 270-278

https://citeseerx.ist.psu.edu/viewdoc/download?doi=10.1.1.403.6804\&rep=rep1\&type=pdf

10) Jančič, Polona (2018). Teaching Social Studies With Games. Vlasta Hus, Faculty of Education, University of Maribor, Maribor, Slovenia. International Journal of Game-Based Learning Volume 8, Issue 2.

https://www.researchgate.net/publication/324123182

11) Kormos, Erik (2016). An Examination of Social Studies Educators to Facilitate Preservice Teacher Development of Technology Integration. Contemporary Issues in Technology and Teacher Education (CITE) Journal.

https://citejournal.org/volume-19/issue-1-19/social-studies/an-examination-of-social-studies-educators-to-facilitatepreservice-teacher-development-of-technology-integration/

12) Mendoza, John Eric. (2020). 50,000 schools shift to distance learning. The Manila Times. Accessed on October 5. https://www.manilatimes.net/2020/10/05/news/headlines/50000-schools-shift-to-distance-learning/776448

13) Mercado, J. N. (2019). Technology Integration in Teaching Science Using Tpack Among Pre-Service Science Teachers of St. Bridget College, Batangas City, Philippines. IOER International Multidisciplinary Research Journal, Vol. 1, No. 1, https://www.ioer-imrj.com/wp-content/uploads/2019/03/TPACK-final-1.pdf

14) Nueva, M. G. (2019). A Literature Review on the Current Technocology in Education: An Examination of Teachers Use of Technology and Its Association to Digital Inequality in School. PADAYON SINING: A CELEBRATION OF THE ENDURING VALUE OF THE HUMANITIES. PDF. 
Social Studies Teacher's Perception in the Use of Educational Websites in Online Teaching in the Philippines: A Systematic Literature Review

https://www.dlsu.edu.ph/wp-content/uploads/pdf/conferences/arts-congress-proceedings/2019/CP-04.pdf

15) Petrie, C. (2020). Spotlight: Quality education for all during COVID-19 crisis (hundrED Research Report \#01). United Nations. https://hundred.org/en/collections/quality-education-for-all-during-coronavirus

16) Sasota, Randolf S. (2021). Will-skill-tool (WST) model of technology integration in teaching science and mathematics in the Philippines. Journal of Computers in Education. https://link.springer.com/article/10.1007/s40692-021-00185-w

17) Subedi, S., Nayaju, S., Subedi, S., Shah, S. K., Shah, J. M. (2020). Impact of e-learning during COVID-19 pandemic among nurshing students and teachers of Nepal. International Journal of Science and Healthcare Research, 5(3), 9.

18) Toquero, C. M. (2020). Challenges and Opportunities for Higher Education Amid the COVID-19 Pandemic: The Philippine Context https://eric.ed.gov/?id=EJ1263557

19) Tschida, Christina M. (2013). Teaching Social Studies Online: An Exemplar for Examining the Broader Implications of Online Methods Courses in Teacher Education. MERLOT Journal of Online Learning and Teaching. Vol. 9, No. 4.

https://www.researchgate.net/publication/276996262_Teaching_Social_Studies_Online_An_Exemplar_for_Examining_ the_Broader_Implications_of_Online_Methods_Courses_in_Teacher_Education

20) UNESCO (2017). UNESCO Task Force on the 2030 Agenda for Sustainable Development https://en.unesco.org/creativity/sites/creativity/files/247785en.pdf

21) Vanfossen, P. J. (2001). Degree of Internet/WWW use and barriers to use among secondary social studies teachers. International Journal of Instructional Media, 29(1), 57-75. https://eric.ed.gov/?id=EJ631216

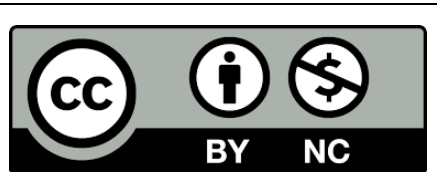

There is an Open Access article, distributed under the term of the Creative Commons Attribution - Non Commercial 4.0 International (CC BY-NC 4.0)

(https://creativecommons.org/licenses/by-nc/4.0/), which permits remixing, adapting and building upon the work for non-commercial use, provided the original work is properly cited. 